ISSN: 1641-4713; e-ISSN: 2081-1160

DOI: https://doi.org/10.36551/2081-1160.2020.26.63-82

\title{
Evangelical coaching: New Age elements in Brazilian Charismatic Christianity
}

\author{
Coaching evangélico: elementos da Nova Era no neopentecostalismo \\ brasileiro
}

\author{
Fábio L. Stern \\ Pontifical Catholic University of São Paulo \\ ORCID iD: https://orcid.org/0000-0001-5642-0299 \\ E-mail: flstern@pucsp.br \\ Silas Guerriero \\ Pontifical Catholic University of São Paulo \\ ORCID iD: https://orcid.org/0000-0003-0014-0217 \\ E-mail: silasg@pucsp.br
}

Recepción: 14.02 .2020

Aprobación: 16.06.2020

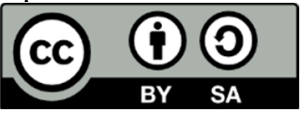

\begin{abstract}
From the 1990s on, the New Age ceased to be visible only among the exclusivist groups of salvific character, typical of the 1970s. Its values began to be disseminated among the broader culture through what was called the New Age ethos. This article seeks to show how these values are seen even among Brazilian Pentecostal Denominations. To this end, we adopt life coaching as an object. We briefly return to the history of life coaching and its relation to the New Age. We then explain how the spread of the New Age ethos into the broader society led to the incorporation of some of the New Age values and practices into even institutionalized forms of religion. Finally, we discuss how life coaching became incorporated into the plethora of religious goods also offered by Brazilian Charismatic Christians, and how Evangelical coaching maintains much of the religious logic of the New Age itself.
\end{abstract}

Keywords: Charismatic Christianity, Pentecostalism, life coaching, spiritual development, New Age ethos. 
Resumo: A partir da década de 1990, a Nova Era deixou de ser visível apenas entre grupos exclusivistas de caráter salvífico, típicos dos anos 1970. Seus valores começaram a ser disseminados na cultura mais ampla naquilo que foi chamado de ethos Nova Era. Este artigo procura mostrar como esses valores são vistos até mesmo no pentecostalismo brasileiro, uma vez que a maioria dos cientistas da religião o ratifica como uma forma de religião que apela mais para o tradicional. Para isso, adotamos o coaching como objeto. Retornamos brevemente à história do coaching e sua relação com a Nova Era. Explicamos então como a difusão do ethos da Nova Era na sociedade em geral levou à incorporação de alguns dos valores e práticas da Nova Era em formas mais tradicionais de religião. Finalmente, discutimos como o coaching foi incorporado à pletora de bens religiosos também oferecidos pelos pentecostais brasileiros, e como o coaching evangélico mantém grande parte da lógica religiosa da própria Nova Era.

Palavras-chave: Neopentecostalismo, pentecostalismo, coaching, desenvolvimento espiritual, ethos Nova Era.

\section{INTRODUCTION}

Studying the New Age in these first two decades of the 21st century is very different from what it was in its early days. Although groups and practices such as extraterrestrial cults and alternative hippie communities continue to exist, it is no longer about the researcher locating specific millenarian and salvationist groups. Today, one must pay attention to how these values, introduced since the 1960s, have spread to the dominant culture as a whole, and how they are being embraced even by traditional religions.

This change is primarily due to the economic character of the West, the cradle of the New Age. Although the counter-cultural movements of 1960 were opposed to imperialism and consumerism in general, capitalism has the substantial capacity to also appropriate progressive ideas that oppose its negative characteristics (e.g., environmentalism, cultural diversity, traditional medicine, feminism) and convert them into yet another commodity. However, whenever capitalism transforms something into a consumer good, it also tends to seek constant expansion of the consumer market to maximize profits. Thus, capitalism uses marketing mechanisms to expand consumption not only within the progressive core from which such values originated but also outside of it.

In the case of a commodified religious good, this would imply that the values of a minor religion can also be addressed to adherents of major religions. In this paper, accordingly, we show how a religion outside the New Age circle can end up incorporating the New Age ethos. The New Age values, therefore, become part of the broader society without being recognized as such. There is no direct identification of the participants to the New Age, let alone a recognition of them as being part of a specific New Age group. The keynote is the emphasis on 
aspects of "spirituality," an umbrella term that can mean almost anything. They see "spirituality" as the awakening of a hidden individual force that can be recognized even by science, provided science is open to conduct research on that "profound being." This conception of spirituality, which at first was unrelated to institutional religions and was shared only among New Agers, is now recognized and valued even by those who practice traditional forms of religion.

This exploratory study examines how life coaching, one of the most widespread New Age manifestations from the 1980s, reaches people beyond specifically New Age groups. Life coaching is also being adopted by Charismatic Christians, one of the fastest-growing religious denominations in Brazil. Evangelical coaching is mainly seen among the new Charismatic denominations - especially the so-called Neo-Charismatics - wherein incorporation of New Age elements increasingly prevails. Furthermore, the Assembly of God, a Charismatic group that has remained undisputedly focused on "the traditional" since its beginning in the early 20th century, has also been incorporating life coaching practices in Brazil.

In the first section of this article, we present our concept of the New Age ethos. We discuss our studies on the subject and the constituents of the New Age ethos. In the second part, we introduce the history of life coaching and its direct relationship to the New Age movements. After listing the main categories of life coaching, we present examples of how the practice of Evangelical coaching contains traces of the New Age ethos. We then conclude that this corroborates our hypothesis of the diffusion of the New Age ethos into the broader society, which includes traditional religions.

\section{New Age ETHos}

It is crucial to bear some points in mind when a scholar speaks about the New Age. The main cause for the confusion among academics who methodologically overestimate the discourse of participants is that "New Age" was initially an emic term, but now is practically used as an etic one (Gilhus, 2014, p. 36). Today followers of what was once called the New Age movement no longer identify themselves under this alias, and many refuse association with this nomenclature, preferring vaguer terms such as "spirituality." Fundamentally, some researchers deny that the New Age still exists and declare that it is a historically located category, which was in its peak in the 1970s. For them, it no longer constitutes a useful category for the humanities. 
However, an association confined to the hippie movement, counter-culture, and the eschatology that foresees the dawn of an idealized world within the framework of what came to be known as the "Aquarian Age" is no longer an accurate picture of what can be academically perceived today as the New Age. The New Age culture is currently structured on a set of values that, in tune with commercial interests, has been absorbed by the broader culture after being relegated and transformed into consumer goods not only for spiritual seekers but also for the more general population (Heelas, 1994; 2008). According to Gilhus (2014, p. 36), sectarian and anti-capitalist groups and millenarian postures and worldviews were the most characteristic expressions of the New Age in its genesis. It comprised mainly left-oriented groups, with great appeal to free love and personal autonomy. In terms of spirituality, those early New Agers regularly borrowed religious ideas from Asian mysticisms, various forms of Shamanism, and folkloric spiritual practices. Today, however, it is possible to find New Age values and attitudes manifested daily by people of different religious and political affiliations (or no affiliations whatsoever), who have no desire to break with capitalism or the prevailing order. This diffused set of values constitutes the present-day New Age ethos.

This hypothesis was proposed for the first time by the Brazilian research group NEO: Núcleo de Estudos de Novas Religiões e Novas Espiritualidades (Nucleus for the Study of New Religions and New Spiritualities) of the Graduate Studies Program in the Study of Religion of the Pontifical Catholic University of São Paulo. After they discussed the state-of-the-art, the members of the research group concluded that what was once identified in the 1970s and 1980s as the New Age is no longer recognized by that name. However, its central values are still widespread in society, including among traditional religions.

The NEO group produced two original papers on the matter (cf. Guerriero, Mendia, et al., 2016; Guerriero, Stern, \& Bessa, 2016), and later, in Guerriero (2018), there was a more in-depth discussion on the prevalence of this ethos in Brazilian society. These studies, as identified by Guerriero (2018, p. 226), are based on a preliminary reading of Hanegraaff (1996; 2005), who distinguishes New Age stricto sensu from New Age lato sensu. New Age stricto sensu is more closely related to the notion of the "Aquarian Age," in which activities and reflections revolved around the aspiration for an ideal world in which a unitarian cosmovision would replace materialism. The New Age alternative societies emerged in this context in anticipation of this utopia. On the other hand, New Age lato sensu is more concerned with personal psychological transformation, 
and the wait for an ideal world is carried only in its name. As their sympathizers began to communicate with other alternative movements, they gradually lost the millennial ideals of the "Aquarian Age." This broader sense of the New Age is less associated with counter-culture, generating what the Brazilian researchers called the "New Age ethos." This last form of New Age is what has been commodified and can be found in the broader society.

The word "ethos" derives from Ancient Greek and originally meant "habit," "custom," or "disposition." The term "ethika" (ethics) originated from this, which was then translated into Latin by Cicero as "moris," the etymological root of the modern word "moral" (Whitney, 1911, p. 3855). From the mid-19th century, scholars began to use it as an academic category related to the customs of a people, and after Bateson (2006 [1936]), it acquired the meaning most widely used by anthropologists today.

Bateson defined ethos as the characteristic spirit and the tonic of a community's feelings, the core thoughts of an institution (Bateson, 2006, p. 70), or the expression of a culturally standardized system of organization of the instincts and emotions of individuals (Bateson, 2006, p. 169). It is beyond the structural and pragmatical (eidos), although it is fundamentally inseparable from it. In this study, emphasis is on the emotional community when referring to ethos: the standardized affective aspects (Bateson, 2006, p. 96), the appropriate behavior (Bateson, 2006, p. 170), what people should feel, and how they should express it. Ethos includes what can be considered funny and what must be treated seriously. It also prescribes when to smile, when to cry, and what kind of sexual behavior must be cultivated; in other words, it prescribes the social taboos and prohibitions of a community. Any disruption from this pattern would be considered a solecism (e.g., an inappropriate joke that causes embarrassment among listeners).

The ethos determines the group's conduct. However, it does not pass without modifications to its members, being fed back by tradition in a circular system. Bateson (2006, p. 170-171) makes a distinction between a strong ethos and a weak ethos, stating that the more deeply rooted ethos is in a society, the higher the possibilities of traditions emerging in parallel from it. It means that social behaviors are the fruit of ethos (they seem adequate) as much as they are the fruit of traditions (previous generations doing the same). In other words, ethos and tradition are self-justified.

Geertz (2008 [1973]) deepened the proximity of ethos to religion, stating that ethos synthesizes religious symbols. In this study, a correlation is described between ethos (emotional) and worldview (rational). On the one hand, ethos 
allows the worldview to become emotionally convincing, and on the other, ethos becomes intellectually reasonable by representing the ideal life prescribed by the worldview (Geertz, 2008, p. 67). This implies that when we talk about ethos, we are talking about emotional conceptions, collective beliefs, community ideals, values, and behaviors that assume an aura of truth. In other words, they seem real and logical because they reaffirm one's beliefs.

The different fragments of cultural conducts and attitudes of its members express a group ethos. Therefore, the Brazilian researchers explored the thematic literature and academic studies for the potential constituents of this hypothetical New Age ethos. They divided the results into three categories: (1) metempirical framework of meanings (beliefs, values, inherent myths, notion of reality); (2) systems of practices, and (3) forms of organization and adherence (Guerriero, Mendia, et al., 2016, p. 24).

On the metempirical framework of meanings, the Brazilian authors declare that Buddhist and Hindu influences led the New Agers to develop powerful beliefs of reincarnation and the concept of "spiritual evolution." The latter refers to a personal quest in which the self must be continuously worked on, allowing for the realization of one's human potential and the expression of one's inner divinity. The authority of consciousness makes the New Agers distrust institutions and traditional forms of religion, believing that diversity of experiences and the power of thought are what truly change reality. For the same reason, there is a strong relativization between right and wrong. Furthermore, the call to consciousness gives New Agers a psychologized interpretation of spirituality in which religious elements - God included - are explained as states of mind, archetypes, or psychic projections (Guerriero, Mendia, et al., 2016, p. 25-26).

Despite the strong relativism attributed to personal attitudes, there is a notion of good and evil among New Agers. They base their notion of good on reaching holistic consciousness, while their understanding of evil would be the disconnected consciousness limited by delusional fragmentations in the material world. There is a strong appeal to monistic philosophical worldviews and the spiritualized use of scientific elements such as quantum physics, electromagnetic fields, and the concept of energy (Guerriero \& Stern, 2017, p. 5-8). They understand magic, religion, and science to be interconnected (Guerriero, 2018, p. 228). However, one can also notice a strong opposition to traditional science, as New Agers considered it reductionist and fragmented because it does not integrate spirituality.

Regarding the systems of practice, New Agers demand for methods of inducing altered states of consciousness, which can be experienced as something 
religious and allows them to expand their mind and connect with the whole. Most of the rituals of this ethos revolve around channeling, which may or may not be related to these moments of altered states of consciousness. Channeling is a specific form of mediumship typical of the New Age in which any human being could connect with both evolved beings from other planes or their inner self. They believe that entities from different religious sources could be channeled (e.g., gods from various mythological pantheons, angels, spirits, ascended masters, extraterrestrials, gnomes, fairies, animals, plants) (Guerriero, Mendia, et al., 2016, p. 25; Hanegraaff, 1996, p. 23). The goal of channeling would be to acquire some kind of knowledge essential to spiritual development (Guerriero, Mendia, et al., 2016, p. 26-27).

Many New Age practices are, in fact, rites from several religious systems (yoga, Qabbala, Theosophy, reiki, astrology, witchcraft, popular Christianity), yet they are considered to serve the purpose of promoting self-knowledge and personal empowerment. With the enormous appeal that nature holds for them, New Agers also embrace forms of religion or rites that aim at a connection with nature, something they assume has been lost by modernity. In this sense, they incorporate elements of Shamanism, Neopaganism, native cultures, and rural folklores, and they also perform several symbolic attributions to natural elements such as stars, planets, crystals, metals, plants, and colors (Guerriero, Mendia, et al., 2016, p. 27).

Alternative therapies are also part of this system of practice. New Agers believe that alternative therapies allow integration between body, mind, and spirit. In this ethos, they elevate healing to the status of a rite; they believe that promoting health would also involve spiritual development (Guerriero, Mendia, et al., 2016, p. 27; Hanegraaff, 1996, ch. 2).

On the forms of organization and adherence, Campbell (1972, p. 127-128) had already discussed that the typical profile of spiritual seekers of the New Age cultic milieu is simultaneously responsible for offering diverse forms of religious experiences and for making it difficult for seekers to become converted into full adherents. With the massification of the New Age ethos, Guerriero, Mendia, et al. (2016, p. 27) also observed that in addition to the already noted fluid posture of religious affiliation, New Age seekers also allow themselves great freedom to transit through different religious systems without bounding by their particular affiliations. Their commitment is toward the search itself, not to a specific institution. Campbell (1972, p. 128-129) also noted that a minority of this cult milieu is required to behave in some way as adepts, to offer the religious goods. 
Although one can find committed people among them, most New Agers have weak religious adherence. A curiosity for general esoteric practices without commitment to groups that offer such religious goods characterizes this weak adherence. As such, hardly anyone objectively recognizes him/herself as or under any variation of the "New Age" label.

Guerriero, Mendia, et al. (2016, p. 27-28) mention that although it is possible to observe some organizations, networks, integrated centers, individualized spaces, sales points, and forms of societies in the New Age ethos, there is significant organizational instability and a fluid transit of spiritual seekers between different groups. The eclectic New Age character and its absence of formal leadership and sacred texts shared by all contribute to this. As capitalism co-opted much of the New Age ethos, there is also a tendency for New Age rites to take place in "saleable" formats for the consumption of religion, such as courses, symposiums, weekend workshops, immersions, and spiritual retreats.

Another strong New Age characteristic that specifically helps this ethos to penetrate traditional religions is the fact that its followers refuse to consider it as a religion. Right from the beginning, New Agers strongly oppose anything that can be formally understood as religion, be it organizational and institutional structures or the external authority of ecclesiastical hierarchy, books, and tradition. Because of this, Heelas and Woodhead (2005) prefer to identify those practices as "spiritualities of life" rather than religion.

Heelas and Woodhead (2005) believe that religion today can be classified into three types: (1) religions of difference, (2) religions of humanity, and (3) spiritualities of life. They traced this model by the emic understanding of the religious about the relationship between God and human beings and nature. At one end of the spectrum, the religions of difference make a clear distinction between God and humans and nature. At the other, spiritualities of life take a holistic perspective and emphasize the fundamental identity in the divine, humans, and nature. Between the two, the religions of humanity try to maintain the three elements in balance.

Spiritualities of life see divinity as inherent to individuals, who consider themselves the authors of their own lives. Their cosmovision is predominantly immanent and holistic. Among the adherents is the search for healing and transformation of personal life through a greater connection with nature, love, respect, education, interpersonal relationships, applied art, and responsibility toward the community. Spiritualities of life start from the assumption that there is a higher self, which is the origin and basis of all that is perfect and true. This higher self would be influenced by collective thinking "collapsing" into the material world 
the energies evoked by thought. They have maximum confidence in the higher self, which they consider the origin of one's spirituality and real human nature. The higher self is also God according to them. For the spiritualists of life, authority comes from within, from a feeling of God. Because of this, spiritualities of life are non traditional forms of religion. They criticize intermediaries between personal experience and spirituality (e.g., priests, ministers, reverends). Spiritualities of life have a perennial and universalistic view of religions. All traditions, according to this group, would refer to the same divine order, as a whole, or emanate from the same universal source. Therefore, instead of focusing on the particularities of religious traditions, the spiritualities of life seek to favor what they consider is common to all (Heelas \& Woodhead, 2005).

Spiritualities of life are not synonymous with New Age, but there are many similarities and affinities between them. Although they were founded in many parts of the world and in various historical periods, in the West, they became more popular after the counter-cultural movements that were born of Romanticism, significantly influenced by Theosophy, Neopaganism, and the New Age movements. It is that Zeitgeist itself that was the fertile ground on which the New Age ethos spread. Therefore, it has become increasingly common for a Christian, who recognizes him/herself as such and remains faithful to the fundamental principles of his/her religious denomination, to see him/herself increasingly as the bearer of an authority that a Christian of old did not possess. The ecclesial authorities no longer have the final word, and the individual sees him/herself as the author of his/her own social and spiritual trajectory.

\section{New AGE AND LIFE COACHING}

According to Berni (2008, p. 88-89), a life coach is someone who monitors coachees (clients) to develop their goals in different areas: romance, career, or sports among others. For many years, the word "coach" has been used almost exclusively to refer to physical coaches. In recent years, however, with the spread of the New Age ethos, the coach's role has expanded. Today, a coach is someone who helps the coachee discover his/her potential and resolve issues. Coaching, therefore, can be considered a technique that brings together different fields of action.

According to Reis $(2014$, p. 27), the idea of life coaching had been in the public eye since the publication of Tim Gallwey's The inner game in 1974, but it was only in the 1980s that it became prominent. The pioneering offer of business coaching in the United States and the United Kingdom began in this period, which 
later led to life coaching itself. At that time, coaches focused on ensuring coachees' professional success, but soon they also began helping their clients in their personal and spiritual achievements. Life coaching, therefore, began to be seen as a process that aims to enhance an individual's overall performance. Since the New Age views the individual as a cosmic being destined to spiritual elevation, the process of life coaching became an essential tool for personal growth.

Berni (2008, p. 30-43) objectively attests to the relationship between life coaching and the New Age, arguing that life coaching is based on transdisciplinarity and the Human Potential Movement, both closely related to the 1960s' counterculture and the New Age movements. The Human Potential Movement, as explained by Hanegraaff (1996) and Berni (2008), emerged within the US middle class after the Second World War. After the United States consolidated its world hegemony, some US citizens began to question the hierarchization of society that led humanity to the disasters of the great wars. A branch of this countercultural group, concerned with the autonomy of people in the face of institutions, led to what was later called the Human Potential Movement: the search to rescue the full potential of being human, which, according to its adherents, is hindered by life in society.

During the 1970s and 1980s, the Human Potential Movement influenced several areas of knowledge. Within psychology, it led to the development of humanistic psychology, headed by theorists such as Abraham H. Maslow and Carl R. Rogers. Humanist thought differentiated itself from behaviorism and psychoanalysis, the more popular currents at the time, by proposing a minor focus on psychopathologies or dysfunctional behaviors. Humanistic psychologists preferred to emphasize the healthy side of the human being, adopting a perspective that all individuals have a natural tendency for wellness, autonomy, and the ability to take responsibility for themselves and others (Berni, 2008, p. 39-40).

According to Hanegraaff (1996), the Human Potential Movement also contributed to the development of the notion of healing and can be classified as a precursor of the notion of psychology among the New Agers. The discourse that all human beings have a natural tendency to health has moved toward the sacralization of the self. Humanistic psychology served as a springboard for the emergence of a broader psychological branch: transpersonal psychology, which is based on transdisciplinarity and has strong influences from the New Age cosmology.

The Human Potential Movement and its offspring - humanistic psychology and transpersonal psychology - have also influenced changes in the conception regarding leadership. From the New Age onward, a leader is no longer 
merely the one in charge. The leader became the one who empowers, inspires, and captivates the subordinates. In the typical New Age orientalism, the great spiritual leaders of Asia unintentionally inspired this new concept of leadership (i.e., Gandhi and the Dalai Lama, famous for their charisma that attracted followers). As Berni (2008, p. 82-83) explains, the good leader has come to be seen as the one who can hear his/her own "inner voice" and can lead him/herself and others wisely. In other words, they seek power from within (self-support).

In the 1970s, New Agers bought do-it-yourself books to achieve self-empowerment. As Hanegraaff (1996) attested, the culture of self-help was central to the New Age. Affirmative action and methods of broadening consciousness were trendy in New Age literature, which aimed at their development and success. New Age cosmology considers that a person creates his/her own reality, and hence, prosperity was attained within what was considered the fruit of spiritual development.

To understand this process, it is necessary to rescue the history of selfhelp. According to Weber (2004), Calvin's doctrine of predestination determined that people were already born bound to salvation or condemnation. The only way they could know their destiny was through clues, and prosperity was one of them. People predestined to salvation would be blessed in life and possess wealth. However, another vital sign is that these people would not boast of this wealth nor enjoy worldly pleasures. This vision caused people to start working to accumulate wealth but to deposit it in savings or invest it instead of enjoying the money. The concept of the Christian call was shifted to the labor market and seen as the vocation for professional activities. This set of factors constituted the so-called Protestant economic ethics that would foster the emergence of the actual capitalist system.

Forsey (2015, p. 33-42) argues that the history of self-help in the United States originates from the Protestant tradition. The early self-help books were mostly religious, and their authors were usually priests who published their sermons focusing on guidelines for following Puritan Christian doctrines and values, for example, The practice of piety (1611), Guide to Heaven (1673), and Bonifacius: Essays to do good (1710). Benjamin Franklin's Poor Richard's Almanac (1732-1757), however, was a watershed because it replaced the focus on Puritan values toward social ascension and prosperity. Franklin's work argued that people should follow the same values already defended by the Puritanical authors before him to prosper (frugality, prudence, order, moderation, and hard work). Notwithstanding, Franklin's approach was more secularized, rejecting ambition as sinful and preaching for the rise of social class through entrepreneurship. Franklin's work eventually paved the way for a plethora of formulas and recipes 
for financial success, and much of the self-help literature began to focus on material prosperity since then.

With the advent of the New Age movement, nevertheless, a new wave of self-help books emerged. New Age thinking emphasized mental strength, the idea that one's will can change the world by adopting various therapeutic techniques (e.g., meditation, hypnosis, past life therapy) to heal "wrong beliefs" responsible for people's failures in their professional and personal projects. For the advocates of this new current, the reason for inequality was not an unjust system or abusive relations between social classes, but spiritual poverty. Forsey (2015, p. 38-42) argues that this emerged as a way to explain these inequalities since the old notion of hard work leading to social ascension was no longer enough. The idea is that if a person releases his/her inner potential through these therapeutic practices, he/she would enrich and attract everything in the universe with the strength of his/her thought, and thus "co-create" his/her reality.

Hindu philosophies began to gain popularity in the United States because of some of their so-called "gurus." In terms of the subject of this article, perhaps the central figure is Deepak Chopra, an Indian physician based in the United States who writes books on body-mind medicine, spirituality, and Ayurveda. In his works, he declares that one can apply quantum physics in various aspects of daily life in seeking financial happiness. Although Chopra is not taken seriously by his medical peers (he even won an IgNobel in the 1990s), he is highly valued in New Age circles. Chopra was responsible for spreading the Hindu notions of karma and dharma applied to prosperity in the United States. Chopra claimed that the universe works according to a "karma bank," and that each act returns to the individual in the form of debt or credit, which one must pay or reap while still alive, or they will influence the conditions of one's reincarnation in future lives. Chopra's teachings, however, presented a novelty: he mixed Hindu thinking with the doctrine of Lutheran Protestantism. By arguing that entrepreneurship is a form of "social service" that pays karmic debts, Chopra met the New Age ethos, which sought Eastern elements serving Western urban culture (Forsey, 2015, p. 48-50).

Life coaching is, to no small extent, the embodiment of this New Age self-help, which is no longer in the form of a book but as a service. As discussed earlier, although the New Age stricto sensu was initially an anti-capitalist movement, as its values began to spread to the broader society, a New Age lato sensu emerged (Hanegraaff, 1996). This new form of New Age, now co-opted by capitalism, transformed the New Age religious goods into consumer goods, and those who offer such goods began to "professionalize" themselves to serve the spiritual 
market. Since at least the 1990s, spiritual seekers no longer necessarily recognize themselves as New Age adherents, but continue to be interested in the spiritualist experiences offered by the New Age milieu (Heelas, 1994). The demand for this has grown, developing a considerable market for courses, seminars, and workshops. Life coaches are, in short, one of the professionals that meet this demand of the spiritual market.

Forsey (2015, p. 62-63) and Hornborg (2010, p. 403-404) identify some features in life coaching that are also main components of New Age self-help. Some of them are (1) the belief that something powerful is dormant within each person; (2) the belief that this power can be released; (3) the belief that everyone can use this power for material rewards; (4) individual-centered ritualistic; (5) self-reliance; (6) self-appointed leaders; (7) transformation through intense emotional experiences; and (8) commercialization. However, as Hornborg (2010, p. 403-404) explains, for these concepts and practices to penetrate the larger secular society and generate more profit for its professionals, they are presented in a new fashion. For example, they call rituals "therapies" to eliminate religious connotations and the ones who administer them refer to themselves as health professionals to give a sense that they are academically qualified for such. Since modern society holds science in high regard, it is common for New Age practitioners to use loose terms from physics or psychology to justify the supposed "scientific effectiveness" of their therapies (Hornborg, 2010, p. 410-413). This occurs in the spirit of what Hanegraaff (2017, p. 415) called "mythologies of science." In other words, coaches do not use scientific terms in the original sense in which scientists use them. This widespread use of scientific terms is a modern reinterpretation of spiritualist meaning. It finds resonance in popular culture because it shares other similar semantic fragments in the great masses.

With today's capitalist society focused on growth and individual positioning, life coaching has gained considerable space. People consider life coaching as an evolved form of counseling, personal consultancy, and psychotherapy. Life coaches end up performing a superficial mix of all without necessarily identifying themselves to each one of those pieces of knowledge. As we demonstrate in the following section, this is how life coaching has become a part of Charismatic Christian churches. It is not a practice that they view as religious or sacred objectively. They think it is a specific form of therapy and counseling to help people face their religious demands on the one hand and the vicissitudes of modern life on the other. 


\section{EVANGELICAL COACHING}

Although not yet a subject commonly addressed by studies of religion in Brazil, references to Evangelical coaching are becoming increasingly prominent in Brazilian Charismatic Christianity, whether through the Internet or other emic Christian media. This attests to the growing popularity and use of this technique in Christian churches, a fact that has not yet begun to be studied in greater depth by the scholars of Pentecostalism and Charismatic Christianity in this country.

Over the past few decades, Brazilian Evangelical churches have sought to do what they emically call "Christian psychology." In addition to pastoral counseling, many Evangelical psychologists seek to defend the idea that there is a field proper to the science of psychology that must act on Christian principles. Such attitudes face much resistance in the Brazilian Class Councils of Psychology, and some self-appointed Christian psychologists have even had their psychology licenses suspended in this country (Otoni, 2014). This occurs largely for three reasons: (1) the Brazilian Federal Council of Psychology forbids the exercise of psychology associated with any religious practice whatsoever; (2) the self-proclaimed Christian psychologists use biblical discourse to naturalize gender inequalities and the submission of a wife to her husband even in cases of domestic violence, making the work of social psychologists difficult; and (3) these selfproclaimed Christian psychologists consider public campaigns for sexual abstinence more valid than sex education for adolescents.

If, in Brazil, on the one hand, regulated scientific psychologists reject such Evangelical moves and have Justice on their side, Charismatic Christians, on the other hand, have found in life coaching an opening to avoid problems of such nature. Although controversial in academic psychology, the Brazilian population at large does not understand the difference between a life coach and a professional psychologist. In realizing this, many Evangelicals who wanted to offer psychotherapy based on Christian values found a gap to act as coaches. After all, coaches do not need to have any higher training nor any professional register in Brazil. This initial discussion is essential to our theme because it would be naïve to consider that every practice of Evangelical coaching reflects the New Age ethos. In some cases, Evangelical coaching is just "Christian psychology" in a new garb performing gay conversion therapies, keeping its agenda against what is emically called the "Marxist gender ideology."

As this is a recent and controversial issue in Brazil, there are no in-depth academic analyses so far in the field. Until the closing of this work, we found 
only one academic production that addressed the presence of life coaches in Brazilian Charismatic Christianity at Plataforma Sucupira, the Brazilian academic database of theses and dissertations. As a way to reconcile interaction between therapy and pastoral counseling, this work places life coaching in the context of Evangelical churches, aiming to show the repercussions of this not only in local churches but perhaps in Brazilian and world Christian communities. According to the author, Evangelical coaches could offer solutions for enhancing the effectiveness of the work done by the churches (Queiroz, 2015). As this is a theology dissertation, the author aims to find ways for action at churches, in this specific case, the Evangelical churches. In this sense, the author's perspective is much closer to practical proposals for insiders than an etic analysis, detached from the object, as one should expect from a scientific study of religion. Instead of a critical view at this emerging use of coaching techniques in Charismatic Christianity, Queiroz was seeking innovations in their pastoral work.

Since this is the only academic text that we could find, we had to resort to primary sources. What we present here, therefore, is only an exploratory character of the universe. Our method did not intend to exhaust the field, and we preferred to adopt a narrative revision methodology. We chose this method because we considered that it would be premeditated to try something more in-depth at the moment. First, we believe that more research is required for a further secure distinction between the Evangelical coaching that emulates New Age life coaching and the Evangelical coaching that is "Christian psychology" in disguise. Second, we observed that there are Evangelical coaching groups that are both at the same time, that is, they are proponents of "Christian psychology" under another name, and they are also absorptions of the New Age ethos. Forthcoming studies must address this complexity.

A prominent example in Brazil that presents itself as both "Christian psychotherapy" in disguise and the New Age life coaching is the Assembly of God. Minister Silas Malafaia, one of its greatest exponents, recognizes the importance of Evangelical coaching. Malafaia has a degree in psychology, and for many years has used his academic title to self-legitimize his religious preaching on the effectiveness of gay conversion therapies. A gay nephew of Malafaia, now married to a man, even declared in an interview that he was forced to undergo these therapies when he was 15 years old (Rohen, 2019). However, it is a misconception to reduce Malafaia's coaching only to the specter of attempting to disguise "Christian psychology." Malafaia defines Evangelical coaching as biblical teaching on how to focus on one's purpose (Mazza, 2019). Since he is responsible for the leader- 
ship classes of the Vitória em Cristo ministry, he includes several of the discursive techniques found in the New Age ethos to train future evangelical priests. To do this, he links the prosperity gospel to notions of personal growth and development of the human potential. In this sense, Malafaia's work is an attempt to not only make gay conversion therapies passable but also an appropriation of elements of the New Age ethos into the Brazilian Evangelical milieu.

In the Reborn in Christ Church, a Charismatic Christian tradition with an upper-middle-class clientele, life coaching is more eloquent and conducted openly. The life coaching preached by this church assumes all the typical characteristics of New Age life coaching but with an Evangelical discourse. Since 2018, the Reborn in Christ Church has been promoting a series of lectures through a specific program called Prosperity Coaching. According to their Facebook page (https://www.facebook.com/OficialProsperityCoaching, accessed January 20, 2020), it is a project focused on professional and financial development created by the apostle Estevam Hernandes, who was marketing director of a large multinational company in Brazil before dedicating himself to the gospel. Hernandes is one of the founders and the main leader of the Reborn in Christ Church. The prominent speakers of the Prosperity Coaching program are Hernandes himself, his wife, his daughter, and minister Tiago Brunet. The Reborn in Christ Church uses the Prosperity Coaching's Facebook page as a means of dissemination, and the program itself has a YouTube channel with several lectures by Hernandes. One of their websites proclaims that they invite speakers to participate in the Prosperity Coaching program to approach fundamental concepts in all areas, to share their vast experience as successful entrepreneurs, and to give hints on behavior and personal, financial, and temporal management (iGospel, 2018). The only significant difference between the coaching promoted by the Prosperity Coaching program and the New Age life coaching is that the speeches of the Prosperity Coaching coaches use biblical symbolism, while New Age life coaches prefer quantum physics.

Regarding Brunet, although he is a common name in the Prosperity Coaching project, he is an independent minister. He has millions of followers on his YouTube, Instagram, and Facebook channels. His messages have no traditionnally religious objectives. His followers are not in search of what one can recognize as the most elementary in traditional Christian churches, such as salvation, grace, liberation, or eternal truth. People seek Brunet for professional success and enrichment. However, the language used by him is religious, full of biblical passages and other theological references (Rosario, 2018). There is a sym- 
biosis between New Age techniques of professional success and the daily life of the Charismatic Christian population in Brunet's works. In Brazil, adherents do not need to participate exclusively in most of the Charismatic churches. They can have external religious activities, so long as those are in tune with the church's worldview and are, of course, Christian. This may explain the success of Brunet. His followers come from different Pentecostal and Charismatic Christian denominations, but his discourse does not conflict with any of them, allowing him to reach a vast audience without provoking the Charismatic Christian leaders. Nevertheless, Brunet emulates the profile of New Age spiritual seekers: not belonging to any affiliation, he transits between different Evangelical groups, establishing exchanges at his convenience accordingly.

It is in the small Charismatic Christian denominations and among autonomous ministers, however, that Evangelical coaching gains a more significant expression in Brazil. Coaches such as Geralda Luciana, a black businesswoman focused on personal and professional growth through life coaching and neurolinguistic programming, ends up being invited to give lectures in small Neo-charismatic Christian churches. Brazilian Charismatic Christians receive Luciana's ready-made phrases (e.g., "those who act have power") with great openness and repercussion (cf. Igreja Templo Formosa, 2019). The fact that she is a black woman also has a meaningful symbolic impact, since most of Brazilian Charismatic Christians are also black. By telling these people that they can overcome their economic struggle with the power of thought and hard work, Luciana provides the Evangelical milieu with much of the New Age ethos concerning prosperity, while pleasing their religious leaders who preach for meritocracy.

Brazilian Evangelical discussion websites also promote the use of life coaching strategies and techniques among Charismatic Christians. The Brazilian Evangelical news portal Soma, for example, has several texts that stimulate life coaching among Christians and present the coach as a qualified professional. In one of these texts, the theologian Leonildo Medeiros encourages the use of life coaching tools for ministers of different Charismatic denominations. According to him, "the greater the use of coaching tools to serve people seeking a Christian leader for help, the higher the spiritual results" (Medeiros, 2019, § 10, our translation).

Still, Evangelical coaching also encounters resistance and criticism among theologians, since they too clamor for space among the congregation. Some priests fear that the use of coaching may corrupt the church itself, classifying it as a trend that hurts Christian religious principles. Samuel Gonçalves (2019), a minister of the Assembly of God, states that it is up to the church to 
proclaim the gospel and enshrine the saints, but that there are always fads entering the doors of temples to corroborate the perversion of ecclesiastical teachings and leading Christians away from biblical Christianity, from what the Scripture presents as irreplaceable truth. Pedro Pamplona (2016), an Evangelical theologian and priest who publishes his opinions in an emic blog, also considers that the prosperity gospel is giving way to the coaching gospel. For many years since the 1970s, the prosperity gospel has been on the rise in Brazilian Evangelical circles, notably between Pentecostalism and Charismatic Christianity. For Pamplona (2016), many Evangelicals are constrained to follow the propositions of the prosperity gospel because it reduces itself exclusively to a goal of material gain. However, he is critical of the new position. For him, it only removes the miraculous divine interference for the material benefit of the individual, replacing it with the action of the latter.

\section{FINAL REMARKS}

This exploratory study sought to identify in Evangelical coaching signs of the spread of the New Age ethos. To do so, we listed the characteristics of New Age life coaching and analyzed some emic materials from the Brazilian Charismatic Christianity to verify similarities and differences. Since this is still a new theme in Brazil, we did not aim to exhaust the field. This study, therefore, aims to provide initial contact with and instigate future academic works on the subject.

In our review, we noticed that the language of coaching is becoming increasingly prevalent in the Charismatic Christian circles of Brazil. This fact allies to the characteristics of the New Age ethos and the autonomy of the individual. As in the New Age, the adherents of the Evangelical churches are no longer tied to the exclusivist practices of their church. In an individualistic logic similar to the New Age milieu, they can look for new strategies of social navigation so long as they do not directly attack the Christian precepts. The logic of professional success and enrichment, which are already part of many Evangelical churches since the emergence of the prosperity gospel, appears under a new guise, acquiring the elements and formats of the New Age life coaching.

Although its final objectives are deeply linked to the spirit of modern capitalism, the New Age has popularized this new discourse that refers to the myth of the evolution of being in spiritual, personal, professional, and financial terms. The dissemination of New Age values throughout society, in what has been called the New Age ethos, now enables individuals of diverse religious affilia- 
tions to also cling to the ideas of well-being and spiritual evolution. In this sense, the values of the New Age ethos are rarely exclusive to any defined religion, becoming seen as values of the whole society.

We assume that the practice of Evangelical coaching can be an empirical example of the broad appeal that the New Age ethos assumes in today's Brazilian society. As possible further studies, we recommend future research on the cosmovision of Evangelical participants and typically New Age participants. Besides, another future study should focus on an integrative review between the religious economic values of the New Age and the religious economic values of the prosperity gospel, identifying their similarities and differences.

\section{REFERENCES}

Bateson, G. (2006). Naven. USP.

Berni, L. E. V. (2008). Self-empowerment, jornada de transformação [Doctoral dissertation, University of São Paulo]. Biblioteca Digital de Teses e Dissertações da USP. https://teses.usp.br/teses/disponiveis/47/47131/tde-16122008-122302/publico/berni_do.pdf

Campbell, C. (1972). The cult, the cultic milieu and secularization. In M. Hills (Ed.), A sociological yearbook of religion in Britain (pp. 119-186). SCM.

Forsey, C. A. (2015). How to become an advice guru [Doctoral dissertation, University of British Columbia]. UBC Theses and Dissertations. https://open.library.ubc.ca/cIRcle/collections/ubctheses/24/items/1.0166462

Geertz, C. (2008). A interpretação das culturas. LTC.

Gilhus, I. S. (2014). All over the place: The contribution of New Age to a spatial model of religion. In S. J. Sutcliffe \& I. S. Gilhus (Eds.), New Age spirituality (pp. 35-49). Routledge.

Gonçalves, S. (2019, June 15). Teologia do coaching: modismo para desvirtuar e corromper a igreja. Gospel Prime. https://www.gospelprime.com.br/teologia-do-coaching-modismo-paradesvirtuar-e-corromper-a-igreja

Guerriero, S. (2018). The New Age ethos in Brazilian society. International Journal of Latin American Religion, (2), 221-233. https://doi.org/10.1007/s41603-018-0060-7

Guerriero, S., Mendia, F., Costa, M. O., Bein, C., \& Leite, A. L. P. (2016). Os componentes constitutivos da Nova Era: a formação de um novo ethos. Rever, 16(2), 10-30. https://doi.org/10.21724/rever.v16i2.29280

Guerriero, S., \& Stern, F. L. (2017). Concepções de energia na Nova Era: o caso da naturologia brasileira. Caminhos, 15(1), 4-25. https://doi.org/10.18224/cam.v15i1.5963

Guerriero, S., Stern, F. L., \& Bessa, M. Q. (2016). A difusão do ethos Nova Era e o declínio de seus estudos acadêmicos no Brasil. Rever, 16(3), 9-39. https://doi.org/10.21724/rever.v16i3.31180

Hanegraaff, W. J. (1996). New Age religion and Western culture. Brill.

Hanegraaff, W. J. (2005). New Age movement. In L. Jones (Ed.), Encyclopedia of religion (v. 10, 2nd ed., pp. 6495-6500). Thomson Gale. 
Hanegraaff, W. J. (2017). Espiritualidades da Nova Era como uma religião secular: perspectiva de um historiador. Religare, 14(2), 403-424. https://doi.org/10.22478/ufpb.1982$6605.2017 \mathrm{v} 14 \mathrm{n} 2.37587$

Heelas, P. L. F. (1994). The limits of consumption and the post-modern 'religion' of the New Age. In R. Keat, W. Nigel, \& N. Abercrombie (Eds.), The authority of the consumer (pp. 94-107). Routledge.

Heelas, P. L. F. (2008). Spiritualities of life. Blackwell.

Heelas, P. L. F., \& Woodhead, L. (2005). The spiritual revolution. Blackwell.

Hornborg, A. C. (2010). Designing rites to re-enchant secularized society: New varieties of spiritualized therapy in contemporary Sweden. Journal of Religion and Health, (51), 402-418. https://doi.org/10.1007/s10943-010-9356-5

Horborg, A. C. (2015). Are we all spiritual? A comparative perspective on the appropriation of a new concept of spirituality. Journal for the Study of Spirituality, 1(2), 249-268. https://doi.org/10.1558/jss.v1i2.249

iGospel (2018). Congresso é marcado por palestras inspiradoras. iGospel. https://www.igospel.org.br/br/noticia.php?m=*7DBB7CFAE0876135CF6CD3CF93DE87C97B177210

Igreja Templo Formosa (2019). Master Coach Geralda na Conferência de Mulheres. https://igrejatemploformosa.com.br/post-read/Master-Coach---Geralda\#

Mazza, L. (2019). O coach evangelico: aulas de liderança com o pastor Silas Malafaia. Revista Piauí, (153). https://piaui.folha.uol.com.br/materia/o-coach-evangelico/

Medeiros, L. (2019). Ferramentas de coaching para pastores e líderes evangélicos? Agência Soma. Cristianismo, comunicação e cidadania. https://www.soma.org.br/liderancacrista/4328ferramentas-coaching-pastores-lideres-evangelicos

Otoni, I. (2014, May 24). Especialistas opinam sobre a 'psicologia cristã', defendida por Marisa Lobo. Revista Fórum. https://revistaforum.com.br/noticias/especialistas-opinam-sobrepsicologia-crista

Pamplona, P. (2016, December 28). Teologia do coaching, a substituta da teologia da prosperidade. https://pamplonapedro.wordpress.com/2016/12/28/teologia-do-coaching-a-substituta-da-teologia-da-prosperidade

Queiroz, S. H. B. S. (2015). Coaching e aconselhamento pastoral: um diálogo possível? [Master's thesis, Faculdades EST]. Base de Teses e Dissertações da Faculdades EST. http://dspace.est.edu.br:8080/xmlui/bitstream/handle/BR-SlFE/591/queiroz_shbs_tm309.pdf?sequence $=1 \&$ isAllowed $=\mathrm{y}$

Reis, F. P. (2014). Uma história do coaching. Revista Científica Brasileira de Coaching, 1(3), 23-30.

Rohen, B. (2019, October 20). Sobrino-neto de Malafaia diz que família o mandou para cura gay: 'um terror psicológico.' Extra. https://extra.globo.com/famosos/sobrinho-neto-de-malafaia-diz-que-familia-mandou-para-cura-gay-um-terror-psicologico-24027151.html

Rosario, M. (2018, December 21). Pastor e coach: Tiago Brunet acumula milhões de seguidores. Veja São Paulo. https://vejasp.abril.com.br/cidades/tiago-brunet-coaching

Weber, M. K. E. (2004). A ética protestante e o espírito do capitalismo. Cia das Letras.

Whitney, W. D. (Ed.) (1911). The century dictionary. Century. 